\title{
Protection of civilians in the law of war: A case study of Myanmar
}

\author{
Ahmed Arafa A. Hammad* | Guo Dexiang \\ School of Law, Zhengzhou University, Henan, China. \\ *Correspondence Emails: superoxidedismutase594@gmail.com | dr_ahmedarafa@gs.zzu.cn
}

\begin{abstract}
The paper is aimed to analyses the Law of War violation in Myanmar. Current communal conflicts in Myanmar among Buddhists and Muslims have cast a pall over the country's transition to democracy. The Rohingya, a Muslim minority group, has been disproportionately affected by the recent round of violence. The Rohingya have been subjected to many human rights violations, which has drawn international attention to the situation. Because the Myanmar government does not recognize Rohingya as a separate ethnic group, they are effectively stateless. Rohingya claim to be indigenous people of Myanmar, despite the government's statements that they came from Bangladesh. The research concludes that as positive as the recent political change has been, the Rohingya's future development does not appear bright. International human rights organizations are urging the global community to pressure Myanmar's administration to amend the Citizenship Law, which effectively makes the Rohingya homeless. The end of this article will give a solution for the Myanmar conflict and protect the Muslim minorities.
\end{abstract}

Article History

Received:

August 1, 2021

Revised:

September 1, 2021

Re-revised:

September 24, 2021

Accepted:

September 26, 2021

Published:

October 21, 2021

Keywords: Common Article 3, Fourth Geneva Convention 1949, law of war, Myanmar armed conflict, non-international armed conflict, prisoners of war, protection of civilians.

\section{How to Cite:}

Hammad, A. A. A. \& Dexing, G. (2021). Protection of civilians in the law of war: A case study of Myanmar. Liberal Arts and Social Sciences International Journal (LASSIJ), 5(2), 124-138. https://doi.org/10.47264/idea.lassij/5.2.9

\section{Publisher's Note:}

IDEA PUBLISHERS (IDEA Journals Group) stands neutral with regard to the jurisdictional claims in the published maps and the institutional affiliations.

Copyright: (O 2021 The Author(s), published by IDEA PUBLISHERS (IDEA Journals Group).

\section{Licensing:}

This is an Open Access article published under the Creative Commons Attribution-NonCommercial 4.0 International License (http://creativecommons.org/licenses/by-nc/4.0/) 


\section{Introduction}

Despite not providing human rights and violating the Law of War, as well as severe prejudices have forced many Rohingya Muslims to evacuate their homes in the transcendently Buddhist nation. The majority of the refugees landed in Bangladesh, while others crossed the sea to reach Indonesia, Malaysia, and Thailand. The problem of national identity and the government's refusal to grant the status and powers of the Rohingya citizens included that because they had fought to restore order in the western region of Myanmar. The prestige of Rohingya democratic engagement, freedom of religion, United Nations (UN) involvement in the Rohingya crisis, and Myanmar officials' violations Law of War are all discussed. Arakan became one of Southeast Asia's most prompt Indianized empires by the 4th Century (Isti'anah, 2018). Dhanyawadi was the birthplace of the Arakanese state. At that time, power was transferred to the city of Waithali. Sanskrit engravings in the area show that Indians organized the first Arakanese regions.

The Chandra regime ruled Arakan. According to the British historian, the Burmese did not arrive in Arakan until the $10^{\text {th }}$ Century CE (d'Hubert, 2018). Arakan has historically been a central part for maritime commerce and socialization between Burma and the rest of the globe due to its position on the Bay of Bengal, dating back to the Indian Mauryan Dynasty. Since the $3^{\text {rd }}$ Century, merchants from the Middle East have interacted with Arakan, travelling there via the Bay of Bengal. According to some experts, Muslims used to exchange routes for travelling to India and China. Since the Neolithic period, India, Burma, and China have been connected by the Silk Road. Seaside Bedouin traders can be traced to the $9^{\text {th }}$ Century in South-East Bengal, along the Arakan coast. The Rohingya people trace their ancestors to this period. Apart from nearby residents converting to Islam, Arab vendors married local women and eventually settled in Arakan. Arakan's Muslim population grew as a result of intermarriage and conversion to Islam. From this early Muslim people group, modern Rohingya trust has plummeted (Acemoglu \& Robinson, 2012).

As agricultural experts, the British policy encouraged Bengali occupants from neighboring regions to settle in Arakan's sparsely populated and wealthy valleys. The Bengal Presidency was extended to Arakan by the East India company. Between Bengal and Arakan, there was no cumulative limit on development, and there were no limitations on growth between the regions. Thousands of people from Chittagong came to Arakan in search of work in the MidNineteenth Century. It is difficult to determine whether these new Bengal homeless people were comparable to those relocated to Bengal's Chittagong during the Burmese victory in the 18th Century. Later, it was brought back to Arakan due to the British plan or some other fleeting people with no ancestry ties to Arakan (de Mersan, 2018).

Much literature has been produced on Protection of Civilian in Law of War in general; however, less scholarly work is done on the Law of War in Myanmar, which is so far from this research. A study conducted by Jacob in 2014 looked at whether the difference between welfare/development-oriented approaches and safety-oriented approaches causes a protection gap for vulnerable populaces practically. This casts doubt on the utility of a securitydevelopment nexus approach to human safety. A politics of protection lens, on the other hand, provides an alternative starting point for studying safety practices in conflict-affected countries and allows for a rethinking of human safety as a transformational strategy to challenging the politics and practice of civilian protection (Jacob, 2014). 
Lut (2021) review the armed conflict, Internally Displaced Persons (IDPs), and protection mechanisms in Kachin State, Myanmar. Due to the armed conflict that erupted on June 9, 2011, between the Kachin Independent Army and the Myanmar government forces, thousands of IDPs have been displaced in Kachin and northern Shan state. The violence took place because the Kachin Independent Army did not recognize the Myanmar Border Guard Force proposal and passing Shwe gas pipeline through one of the Kachin brigades. The IDPs need humanitarian assistance, lack of legal protection as the government still blocks the international humanitarian provided by UN agencies and other non-UNG agencies. Because both sides want to employ force, the peace negotiations are still weak and hazy. Currently, the political environment is unpredictably unstable. International humanitarian assistance providers are less present, and IDPs have no legal protection or unsecured human security (Lut, 2021).

In 2016, the five broad concepts of civilian protection outlined in this conclusion have been presented to challenge monolithic accounts of civilian protection in global politics (Jacob, 2016). Civilian protection is a highly disputed area of practice in global politics that interacts with ethics, law, politics, and military strategy, as shown by differences among authors in this book on fundamental protection frameworks and ideas. As a result, civilian safety is not an afterthought when it comes to the fundamental political and strategic measures intended to bring violent conflict to a close. Rather, it is integral to the politics and practice of these answers in their very essence.

In other words, the notion of civilian protection is effective and successful in international politics. For instance, when used in a speech act, it has the potential to crowd substantial action by strong nations and alter the course of large-scale wars. Civilian safety, on the other hand, is still inadequately understood in connection to its many and diverse forms, especially in internal conflicts and nonconventional warfare. Monolithic views of civilian protection as a distinct operational variable apart from the larger picture of armed conflict goals may also distract from giving assistance to people, communities, and key domestic actors who are most in need of change and resilience (Jacob, 2016).

\section{Methodology}

The method to qualitative research has been implemented concentrating primarily on the protection of the civilian in accordance with the law of war with a main focus on Myanmar. Publications by many prominent authors, international law academics and attorneys are consulted for this research. The explanations that have been based on these writers is, for an instant, professors of law of war. Furthermore, these research methods were utilized since the study is a library-based one including many publications, articles, international journals, reviews, and published papers. The main data sources are online sites and global books compiled from web pages.

\section{Myanmar conflict: Review and discussion}

Throughout the year, the conflict between the Burmese army and ethnic groups in Rakhine, Karen, and Northern Shan States escalated, displacing many ordinary citizens. Actual abusive behavior of government authorities has included mass executions, torture, sexual violence and the destruction of property, to name a few. Armed forces have conducted airstrikes and shelling against ethnicities in infraction of the Laws of War. Anti-Personnel booby traps and forced enlistment of minors have been involved by both the government and non-State actors. 
Although only half of the country's armed groups participated in the October 2015 ceasefire signed by the previous Thein Sein government, most armed groups have formed peace agreements since then.

The Rohingya people have been subject to ruthless campaigns of inhumanity and have continuously faced different types of abuse, consisting of constraints on the right to wed and have children. Some Rohingyas must have government approval for their marriages, and a few zones have imposed a Two-Child restriction (Menager, 2017). As a consequence, around 60,000 Rohingya kids and adolescents who encroach these limitations are unable to register, making them unsuitable for any civilian organizations, including regulations. Impossible improvements Even to travel to a nearby village, Rohingya must obtain government permission. Applying for grants to support development projects involves a lengthy application process, has many hidden fees, and is very thorough. The barriers to development prevent the Rohingya from having access to the post-Basic guidance, the market, business opportunities, and social welfare.

In Rakhine State, the Rohingya people are required to perform this work exclusively by children. Claims of the denial of a fair system The Rohingya regularly suffer deprivation of property, corporal punishment, violence, and torture by authorities, as well as torture due to experts. The state of Rakhine is one of the poorest areas in Burma. The Rakhine ethnic group has been subjected to monetary detachment and social restriction by the Burmese largest share and central government for quite some time. As Buddhists and a minority group in the eyes of the Rakhine, the Rohingya have been denied the same rights and opportunities Rakhine enjoy. Despair fuels Rakhine enmity toward the Rohingya, whom they see as foreign people vying for limited resources (Fong, J, 2008).

\subsection{Major violations in Myanmar}

For prisoners to continue acting as officers for the military while in prison raises grave humanitarian concerns. According to Mr. Kellenberger, the Myanmar government's activities have resulted in enormous suffering over a large number of people in Conflict-Affected areas. "The International Committee of the Red Cross (ICRC) has more than once attracted regard for this maltreatment; however, it has failed to put a stop to them."

The conclusions are located on the opinions of ICRC delegates and several reports of maltreatment gathered through the ICRC between 2000 and 2005 during private discussions with many ordinary people and inmates. In Burma, deliberate mistreatment of prisoners and ordinary citizens is the source of legitimate concern.

Many prisoners in Myanmar's jails have been forced to work as security staff for the military because of laws enacted by the country's legislature. This general and codified procedure has resulted in the mistreatment of prisoners and exposed all of them to the risks of armed warfare. Former prisoners utilized as security guards have suffered from tiredness and lack of nutrition as well as being exposed to humiliating. Several individuals have perished. However, the ICRC has portrayed it in various ways, several provisions of the Law of War are violated (MacInnis, 2007).

Males, females, and kids living in Conflict-Affected areas along the Thai-Myanmar border have been subjected to enormous abuses by Myanmar's military. These factors have included 
the removal of food and resource production methods. The military has heavily limited these zones, thus making it impossible for people in the village to work in their areas. This has thrown the economy into a tailspin and made a bad situation severe. Furthermore, the military has committed various acts of heinousness, including murder, against residents of these territories and has exposed them to self-assertive seizing and detainment. They have also forced villagers to either directly support military operations or lose their homes.

The military's actions and activities have caused a feeling of constant dread among the population and have forced many people to join the ranks of the dislodged or flee the country. The retread mistreatment of males, females, and teenagers living near the Thai-Myanmar border violates Law of War agreements.

\subsection{Myanmar and non-international armed conflict}

Article 03, common to all the four 1949 Geneva Conventions was a main strategy for a nonInternational armed conflict. However, this article was deemed unsuitable due to the fact that non-international armed conflicts have resulted in around 80 per cent of the world's civilian casualties since 1945, that non-international armed conflicts are, on average, more brutal than international conflicts. There is a purpose for the present Protocol to broaden the scope of the law of armed conflicts to include internal conflicts. At its fourth session, the Diplomatic Conference decided to curtail and improve the Protocol out of concern that it could harm state control, prevent governments from effectively maintaining peace within their borders, and be used to legitimize outside mediation (Sivakumaran, 2012).

Article 1's restrictive significance of the material field of utilization will have a narrower impact on internal conflicts in Protocol II than Article 03 of the 1949 Conventions. Though, Article 04 contains the fundamental principles. The original strategy for creating neutral and compassionate alliances had been more limited than expected. Nine police officers were killed in an ambush in the Maungdaw region of northern Rakhine State due to violent outbursts in the Maungdaw. As a result of the fact that well-equipped Rohingya activists completed both the hidden and successive attacks, the organization initiated advantageous efforts to discover the verified attackers while protecting the area and restraining access to self-governing media and rights panels for assisting social gatherings. Rohingya villages were subjected to various abuses following the protection exercises, such as deprived killings, assault and other sexual violence, torture and mishandling of extra catches, and unlawful fire.

During a military operation, helicopter gunships were used. As of the time, the assembly claimed to have captured and over 300 declared. The neighborhood packs discovered several different tactics and techniques in the expert's arsenal. Satellite imagery discovered that there were 430 buildings destroyed in three different towns in the Maungdaw region; in each case, the towns were destroyed by fire. The government's restrictions on charitable organizations have triggered an acute lack of aid and hunger, and more than 30,000 ordinary Muslim settlers continue to stay displaced. The ruling body has persistently neglected to thoroughly or sufficiently research Rohingya abuse and failed to propose a UN help search for an investigation into the violent action.

The never-ending emergency in Maungdaw serves as a powerful reminder of the most brutal and far-reaching malice against the Rohingya. Since ethnic cleansing efforts, it did more than 120,000 Rohingya and left them in Rakhine State. Because of development constraints and an 
absence of availability to jobs and fundamental administrations, the situation for exceptional Internally Displaced Persons (IDPs) and, a while back, resettled people remain needy. The decision to deny citizenship to the Rohingya, who do not appear on the official list of 135 ethnic groups eligible for citizenship rights under the 1982 Citizenship Law, has sustained ongoing human rights abuses. These abuses include restrictions on development, access to medical services, employment, shelter, and education, as well as arbitrary detentions and detentions without charge. IDP camp accessibility is actually severely limited as a result of authorization needs, security inspections at security gates, opportunity limitations, as well as curfew opportunities. The people's lives in these communities are further complicated by their deplorable conditions, severe traffic, and wellbeing organizations. The new Burmese government established two groups in September to resolve factional issues in Rakhine State: an organizational advisory panel and a nine-member national/international disclaimer panel chaired by former UN Secretary-General Kofi Annan (Kofi Annan, 2017).

The repeated abuse reported against males, females, and teenagers living along the ThaiMyanmar border violates numerous laws of war norms. The State Law and Order Restoration Council (SLORC)'s use of torment, which includes aggression and other harsh treatment, racked up on ordinary people and outfitted members during military tasks violates the Law of War and international human rights regulations. In breach of the Geneva Conventions, the Burmese military has been accused of abusing Prisoners of Wars (POWs) who were present at a part of the guerilla group. The reports of indiscriminate attacks on ordinary people and their communities, extrajudicial murders, and the forced relocation of huge populations have all been made in the recent past. Research by Reprieve International found that ethnic-based groups have also provided relief from global human rights violations, including enforced disappearances, coerced enrollment, and extortion (Sassòli et al., 2011).

It is clear from these allegations that Burma violated Common Article 03 of the Geneva Conventions on August 24, 1992. It will continue to do so for as long as Burma is aware of its obligations under the Geneva Conventions. It must also consider the overarching premise of international law, which states that all states must respect the fundamental objectives of humanity in times of both peace and war. The Martens Clause in international law supported human rights insurance norms that have been primarily harmonized despite conflicting national interpretations of binding treaties. It is not without limits, as the privilege of individuals and groups in conflict to choose the procedures of battle is the right to bestow destruction on the enemy. A distinction should be made between those who care about military activities and those with a civilian populace. The civilian population is not damaged excessively. No military troops should cause harm to civilians.

The administration's incapacity to combat the wide range of privileges regulations that have been used to censure free speech and arraign dissenters for quite some time has resulted in limitations on the right to freedom of expression and assembly. In Burma, women's and young women's rights remain fragile, particularly regarding the violence associated with armed conflict. Sexual viciousness by the military and ethnically motivated groupings has been evidenced, and the re-emergence of violent conflicts in Kachin and Northern Shan jurisdictions has compounded the issue. Breaches are aided by a near-total lack of accountability and the lack of a normalized complaint resolution system (Harroff-Tavel, 1993).

The ICRC has visited prisoners who fear that if they are released or swapped, they will be subjected to violations of their human rights or exposed to other threats, for instance, 
counterterrorism within their own country. As a result, experts will be privy to the individual's fears. It is not the ICRC's responsibility to determine the extent to which the dread has become entrenched in society. The experts are the ones who have to commit fully to do so.

In any event, the ICRC often asks for direct pre-flight discussions with the prisoners in order to be able to communicate any misgivings to the exchange experts. Another issue that the ICRC is concerned about is the actual exchange technique: the ICRC lends its authority from time to time to help prisoners, especially POWs, to return to their countries of origin. In this regard, it is important to stress that the ICRC will not be able to lend its services if it is concerned that operations would breach international law. Furthermore, the ICRC is an inspiration as a proper approach to those who need to return, regardless of whether they have given their informed consent to the exchange, as it may be contrary to its benevolent instruction to participate in exercises which may be dangerous for the person concerned regardless of their legal nature. Whatever the constitutionality of the exchange program, the ICRC never supported the funding provided to administrators had allocated to aid the entrance of people who did not want.

Despite accusations of moreover 115 forms of sexual violence perpetrated by the Burmese military since the conflict resumed, few charges have been readily and publicly disclosed. The media and neighborhood groups reported numerous assaults and other sexual assault events of Rohingya women and young girls during clearance operations in the Maungdaw area. The authorities have barred all reports of sexual violence, and the military shutdown has prevented independent investigations into the abuse. This reticence to address sexual misconduct among service members is another example of how the military hides these problems. It is a ghastly crime against humanity.

\subsection{The doctrine of Law of War}

The investigation looks into the current non-International armed conflicts in Myanmar, infringements of Law of War standards concerning Common Article 03 of Geneva Conventions and additional Protocol II, and other essential variables connected with the inhumanity. In Maungdaw and Sittwe, the Myanmar Red Cross and red crescent have provided caring assistance to those in need. The crisis has mainly centered on food, health, safety, and sanitation, along with water, hygiene, and nutrition assistance, job and training opportunities, and health care for those eligible for the benefits of international law (Khan et al., 2019). The government refused the interaction, regular abuse, prisoners, regulations, and approaches were examined, and purposeless attacks were investigated. In the meantime, the movement will continue connecting with new systems to provide crisis help and support while focusing on recovery and long-term betterment. In Rakhine State, where everyone is trying to help those affected by the inhumanity, no one is segregated or taking sides basis on religion, racial group, ethnicity. They only provide helpful guides in response to requests (Fleck, 2021).

\subsection{Violation of Law of War in Myanmar}

The Muslim ethnic minority continues to face various constraints, including limited assistance and violations of Law of War. The Rohingyas' growth opportunities are severely limited, and by far, most of them have been effectively refused citizenship. They are also vulnerable to extortion and self-assertive tax collection, confiscation, limited removal and home destruction, and financial constraints. Actual infringement and risk to individuals sheltered under Law of War remain to be treated as restricted workers on streets and armed forces sites. In the last 
decade, however, restricted employment in Northern Rakhine state has diminished. In addition to compromising some other fundamental human rights of the Rohingyas, these measures are detrimental to the Rohingya people. They don't seem to be targeted in the same way or on the same extent as some other ethnicities in Rohingyas or the whole (Winminton, 2012).

Myanmar's government has not only continued to monitor but has also imposed restrictions on uprooted groups' access to humanitarian aid. The ICRC is prepared to do everything it takes to ensure the success of its Anyone in need of assistance may turn to the (ICRC) and Red Crescent Movement (RCM), which has an internationally recognized command under the Geneva Conventions, the Statutes of the International Red Cross There were several thousand Muslims who were never again able to get humanitarian aid in Arakan State due of the cruelty incident in June 2012.

This effect is no longer limited to those who have been uprooted. The deep Muslim community that has been split by motion honestly in similarity with continuing their lively hoods walk secondary providing locations due to hostile Arakanese community then limits about move aided by Burmese wellness authorities. According to Office for the Coordination of Humanitarian Affairs (OCHA), roughly 98\% of questioned IDPs do not have the right of passage to post-retail markets (Winminton, 2012).

When the attacks on Muslims became more frequent and severe, foreign humanitarian groups were compelled to relocate their staff from northern Arakan State and Sittwe to Rangoon due to security concerns. However, due to the Burmese government's limitations on Rohingyas' freedom of movement, it was impossible to remove the local Rohingya employees. Following the unrest in June, the authorities prohibited all humanitarian organizations from returning to Arakan State for an extended period. According to a senior aid official who spoke to Human Rights Watch, one Non-Governmental Organization (NGO) made an official appeal to the government for journey licenses for its employees. Following that statement, they said in the last line in response to this statement that foreign employees would not be allowed to leave until peace and calm prevailed.

In order to ensure all people existing in Arakan State may resume their vocations exercises and have access to basic services, UN Resident Coordinator in Burma Ashok Nigam says it is critical to address the issue of development opportunities for the impacted individuals, whether they have been uprooted or relocated. Human Rights Watch spoke with a Rohingya man who had been displaced from his home in Yan Thei, Mrauk-U Township, at the beginning of November. he said that we had 2,460 people here before the Arakanese attacked. The government said they would provide food, oil, and other necessities, but they have yet to do. So, we cannot buy anything since we cannot go to the market or town (Story, 2012).

\subsection{Serious threat to protection of civilization}

Law of war's objective is to limit the misery affected by war and to mitigate its consequences. Its regulations are the consequence of a balancing act between, on the one hand, military demands and, on the other, human laws. The Law of War is a delicate subject that cannot be tampered with. Law of War is violated in all situations in Myanmar for the survival of human values and, very often, for the sake of protecting life. Based on Geneva Conventions Article 01, all states have a responsibility to respect and ensure Law of War. This involves holding all nations, even those not involved in a particular armed conflict, accountable for taking all 
feasible and reasonable steps to ensure that the parties follow the norms of humanitarian law applicable to that combat (de Chazournes \& Condorelle, 2000). It is a responsibility to encourage conformity with that law and to act "with reasonable care to prevent breaches of humanitarian law from occurring or to ensure their suppression as soon as they occur." Only circumstances recognized as armed conflict are covered under Law of War (de Chazournes \& Condorelle, 2000).

There are two approaches for determining the consequence of the Myanmar conflict. First, whether the war has progressed to the point where it can be considered a prolonged conflict, with a continuous period of conflict that extends beyond occasional actions. Second, an armed confrontation may only occur between clearly recognized armed organizations or State forces that are well-prepared, have a transparent and recognizable command structure, and sustain army operations. In addition to Human Right Law, Law of War applies. The presence of an armed battle does certainly not change the State's continuing Law of War commitment to safeguard the right to life by allowing humanitarians to access areas where that right is essential.

Even if the Northern Rakhine State situation is determined to constitute armed conflict under Law of War and Human Right Law will continue to apply, except for any permitted derogations the State may justify. Moreover, even in the face of posed threats, some aspects of Human Right Law, like as the ban of torture and other shapes of inhumane treatment, continue to apply with full force and are unaffected by any condition of weakness or stalemate. The right to life would continue to be protected, even in the case of an armed conflict, but what constituted an unrestricted adversity of life in a context of prolonged warfare would vary on whether it was compatible with Law of War (Lane, 2016).

When it comes to human rights abuses, such as the detention of civilians, the ICRC has been outspoken in its condemnation. It called on Myanmar's government to take immediate action to end these abuses and prevent them from happening again due to severe humanitarian concerns. The military continues to employ prisoners as porters. To make matters worse, thousands of people in conflict-affected regions have been harmed by the government's actions. "The (ICRC) has repeatedly expressed concern about these atrocities, but the Myanmar government has failed to put an end to them. Even the authorities have refused to enter on many occasions" (Shesterinina, \& Job, 2016).

\subsection{The common Article 03 of Geneva Convention and additional Protocol-II}

Military conflicts are dominated by elements that conducted entirely inside a particular country's borders: they are non-international battles in nature. The intervention of the military of another State, backing the legislature or the agitators, is a traditional feature of many such internal armed conflicts. Humanitarian law's substantive criteria governing non-global armed clashes are much simpler than those used by their international counterparts. They are derived from a single primary source, namely article 03 of the four 1949 Geneva Conventions, which requires sides to an inward clash to adhere to specific basic humanitarian laws. However, it is essential to notice that common Article 03 imposes restrictions on both governments and radicals without granting them any special treatment or privileges. Additional Protocol II, ratified in 1977, extends the Geneva Conventions' article 03 to include a slew of new provisions. This is a remarkable commitment to enhancing humanitarian protection at times of internal conflict. Convention II, on the other hand, is used to a lesser degree than article 03. It 
only applies if the radical party has power over a significant section of the national area (Meron, 1996).

Article 03 and AP II apply if a non-international armed conflict occurs near one of the 1949 Convention's contracting states. It also applies whether the war is internal to the country or between the government and rebel forces, or between rebel powers themselves. This sentence is expanded in Protocol II, which is an annex to this article. Article 3 provides worldwide minimum insurance to non-active participants in risks, including military personnel in certain situations. These are formal military battles with equipped dissidents or supplied groups fighting each other. Article 3, essential to the four Geneva Conventions and AP II, put out a more limited set of criteria for inward outfitted conflicts (Azeem, 2016).

In comparison to international criminal councils, which were established to address an exact circumstance and a specific essential, it has been determined that national legislation and national courts are more effective in releasing the use of introductory article 3 within the parameters of the constitution of the State and the law of that State. The worldwide decisional documents make the customary understanding of common article 3 much more difficult to comprehend. Any effort to develop a precise clarification will show that the city laws communicate the altering sizes of altruistic regulation relevant for non-international conflicts rather than seeking to require the reassurance provided under common Article 03 in the context of wrongs as well as misdeeds against humanity that have officially brought sufficient shame to the corpus of practical rule (Susetyo, 2019).

If the agreements do not explicitly identify the guilt of the forbidden conduct, customary law and internal laws have been fundamentally suspected of filling the gaps. As far as the common circumstances of Article 3 are concerned, when a question is raised as to whether or not customary law is involved, the substance of the regular article is not recognizable because of uncertainties involving various understandings and national traditions (Susetyo, 2019).

\subsection{Indiscriminate attacks}

The threat or use of force against other nations is expressly and unequivocally banned under the UN charter. Thus, using force is forbidden. Since 1945, war has never again proven to be an effective means of resolving differences between nations. So why are we debating global rules for handling outfitted conflicts and their consequences when the UN Charter prohibits the use of force to limit international relations (Albert \& Maizland, 2020). While Rohingya have been exposed to indiscriminate attacks for a long time, including murders, assaults, arbitrary detention, and torture, two recent incidents have escalated brutality against the group. Longsimmering tensions erupted in public brutality among Rohingya and Rakhine, killing hundreds and displacing over 140,000 people. Buddhist monks and local Rakhine lawmakers, according to Rohingya witnesses, have been responsible for a number of assaults. According to reports, the brutality forced Rohingya from their homes, along with condition security powers falling short or rejecting to stop the brutality and occasionally taking part in it. (McPherson, 2018).

In 2017, UN Human Rights Council set up a fact-finding mission to gather information about these alleged atrocities. However, the Burmese government has vowed not to cooperate or provide experts access to the areas where mass barbarities allegedly happened. There is no doubt that the Muslims of Myanmar, who make up around 4\% of the population, have endured many hardships. No matter how much progress has been made in the political arena in favor of 
law-based administration and universal weight, their fights the Rohingyas' plight has come to light in a big way. Some Non-Rohingya Muslims in Myanmar's other regions have also had difficulty gaining citizenship and establishing a presence in the public sphere. However, they have been treated like peasants wherever possible. In the face of increasing separation and cruelty, as well as the lack of progress in citizenship security, many of these people have fled the country in search of (Mohdin, 2019).

\subsection{Grave breaches of the Fourth Geneva Convention}

The Law of War is a collection of international laws that govern the management of prolonged conflict. According to the article, this norm applies to the armed forces of state and extended non-state organizations. Atrocities do not constitute a breach of Law of War. Burma's nonstate-equipped groupings, especially the Burma army's intermediate armed forces, have also committed grave human rights violations, including restricting tyke combatants' work enrollment, and using landmines to murder civilians. In any case, these organizations have suffered these abuses to a much lesser level than the Burmese army (Jaythoum, 2020).

They consist of unwavering execution, agony, and the illegal and indiscriminate destruction of the property. In order for an atrocity to occur, there should be a condition of equipped conflict in which (IHL) applies. inflicting exceptional lasting agony or barbarous treatment is considered a grave breach under Articles 50, 51, 130, and 147 of the fourth Geneva Convention, and which the perpetrator may be prosecuted. They broke four Geneva Conventions and refused assistance, which may amount to the same thing to a hungry civilian population in a war scenario (Bergsmo \& Tianying, 2018).

\subsection{Solutions for Rohingya's problems}

Myanmar should be placed under international pressure to improve its response to the Rohingya people. The truth is that the Rohingya people's desperate condition is driving them out of the nation. The migrations will continue uninterrupted as long as people are desperate. China, which has a large financial presence in Myanmar, can apply enormous pressure. Even while China claims to encompass non-interference in other nations' internal affairs with its rigid interpretation of the concept of sovereignty, its growing power necessitates that such a stance be reassessed. China has a responsibility to protect the Rohingya people as a member of the international neighborhood. However, changing the views of the Burmese authorities would be difficult, given that they have been vehement in their denial of accusations that they are too responsible for the situation in general (Olumhense, 2017).

An advisory opinion of the International Court of Justice (ICJ) on any criminal matter under Article 96 of the UN Charter and Article 65 of the ICJ Statute may also be requested by the General Assembly or the Security Council. The UNGA and Security Council and other UN bodies and organizations have the power to request a consultative opinion on a criminal issue that has arisen as a result of the conflict in Myanmar (Crossman, 2014). The Opinion, on the other hand, will not be legally binding in any way. Bangladesh is bearing the brunt of the Rohingya displaced population. Because the inconvenience was previously created via the Myanmar government. Bangladesh wants the Rohingyas to return to their homeland. In Myanmar, the majority of Rohingya are stateless. In the absence of documents, many went to Bangladesh, including the infants: without differentiating evidence, they have little chance to acclimate regularly to the general public. How might they be returned? UN must engage in 
efforts to compel Myanmar to repatriate its citizens and provide insurance and protection (Kipgen, 2014).

With guidance from the UN, the entire approach must be examined. The Organization of Islamic Cooperation's leading figure in Myanmar said the UN should be involved in Rakhine State to ensure that the growing viciousness against Rohingya Muslims does not lead to the kind of annihilation that happened in Cambodia and Rwanda. Since the conflict began on October 9, 2016, it has claimed more than 80 lives and forced at least 66,000 people to flee Bangladesh, yet it is no longer just a local issue, but one that has global implications (Wilmshurst \& Breau, 2007)

Myanmar's government should fully implement the Rakhine Commission's recommendations. All legislation that intentionally oppresses the Rohingya, such as the Protection of Race and Religion act and the 1982 citizenship law, should be repealed or amended by the legislature. The Myanmar government must handle the tensions that are affecting the Rohingya Muslim minority. The OIC represents fifty-seven countries and serves as the Muslim world's collective voice. Since armed force duties began in the north of Rakhine State, displaced individuals, residents, and human rights groups allege that Myanmar troopers have carried out extrajudicial executions, molested Rohingya young ladies, and destroyed dwelling quarters. As a result, the international community should have a beneficial strategy and view our country's combat condition broadly on the battlefield, addressing the marvelous monstrosities dedicated to the ethnic gathering. Zaw Htay chastised Malaysia for its role in the conflict, saying the nation needed to manage its internal problems and avoid inciting extremism and bloodshed in Myanmar. The specialists must focus on the issue in Rakhine systematically and accurately. They should work hard in a bad situation with this internal conflict to prevent it from occurring again (Ahmed, 2018).

The UNSC should urge that free examiners, including Special Reporter Lee and members of the Fact-Finding Mission, have immediate access to Rakhine State. UNSC needs to bring up Rakhine State's situation concerning international criminal court (ICC) sanctions on weapons and concentrate on authorizing top military commanders with order responsibility in Rakhine State. The government must build a more inclusive society without regard to religion, citizenship status, or race. The government should take part in essential discussions to stop the conflict in Kachin and Shan States. If the Rohingyas are to be repatriated, they must do so on purpose according to the 1951 Refugee Convention and nonrefoulement norms (Shesterinin \& Job, 2016).

\section{Conclusion}

For more than six decades, Myanmar has seen non-international armed conflict, including conflicts between ethnic groups and the military in specific locations throughout the state. The Rohingya minority are subjected to cruelty both at home and away, and they have no desire to lead a dominating life at this time. The government of Myanmar disputes that they profit from their presence in Rakhine state, their home since the seventh century. Since the military regime took power in 1962, they have been subjected to indiscriminate killings by the State. The ICRC supports humanitarian relief to people in Myanmar who have been affected by armed conflict and other violent situations. They have been accessible throughout Myanmar, including Kachin, Shan, and Rakhine states, for over 30 years. Their response is extensive, including both crisis and long-term assistance. They provide access to safe drinking water, social 
insurance offices, and improved living circumstances, promote humane global legislation, and disseminate information about landmine risks. They also visit detention facilities to improve prisoners' living circumstances, reestablish contact with their loved on, and reunifying family members. A large number of their programs are carried out in collaboration with the Myanmar Red Cross Society. Despite official assurances and contrary to expectations, Myanmar is entirely preoccupied with ethnic cleansing and massacres of its unwelcome minority Muslim population. These approaches are evident in the state security forces' actions and inactions during the 2012 slaughter, in the administration's refusal to protect the Rohingya from further savagery by the State's Buddhist gathering, and in the administration's refusal to provide a lifesaving guide to the Rohingya IDP camps, where they are currently starving.

Meanwhile, the international system headed in Rwanda and the former Yugoslavia, led by the USA, the EU, the UN and ASEAN, must not allow the ethnic cleansing and destruction of Myanmar to continue. Rohingya relief should also emanate from ASEAN, as it is the regional organization most suitable for tackling Myanmar's human rights abuses. They may band together with the UN and other nations to raise a worldwide voice on the Rohingya crisis, to the extent that they can impose pressure on Myanmar. The OIC also decided to establish a special board of trustees to handle accusations of human rights abuses against Myanmar's Rohingya minority. This ethnic violence also harms Myanmar, Malaysia, and Thailand, which are all ASEAN member nations. Essential trading partners, for example, the USA and the EU, must work with ASEAN to carry outbound mutually voluntary force to effect change over in Myanmar in order to protect the Rohingya. For financial and political concerns with Thein Sein's legislature, the international system has so far failed to take authorized action to end the breach of human rights in Rakhine state. Furthermore, as the headquarters of ASEAN in 2014, Myanmar has consistently obstructed efforts by member nations to resolve the Rohingya problem. The international community and Myanmar's nationals have not sought every peaceful solution needed under the RTOP to deal with the Rohingya. This needs to change as quickly as time allows.

\section{References}

Acemoglu, D., \& Robinson, J. A. (2012). Why nations fail: The origins of power, prosperity, and poverty. Currency. http://www.jumpstartgym.com/wpcontent/uploads/2010/viewp/Why-nations-fail-mit-economics.pdf

Ahmed, F. B. J. (2018). Rethinking UNHCR and OIC response to forced migration. AlShajarah: Journal of the International Institute of Islamic Thought and Civilization (ISTAC), $1-26$. https://journals.iium.edu.my/shajarah/index.php/shaj/article/view/735/328

Azeem, I. (2016). The Rohingya: Inside Myanmar's hidden genocide. C. Hurst.

Bergsmo, M., \& Tianying, S. O. N. G. (Eds.). (2018). Military Self-Interest in Accountability for Core International Crimes (Vol. 25). Torkel Opsahl Academic Publisher.

Crossman, L. (2014). Myanmar's Rohingya Refugees the Search for Human Security. Georgetown University.

de Mersan, A. (2018). Ritual and issues of ethnic integration in the borderlands of the State of Rakhine/Arakan (Myanmar). In Routledge Handbook of Asian Borderlands (pp. 151161). Routledge.

d'Hubert, T. (2018). In the Shade of the Golden Palace: Ālāol and Middle Bengali Poetics in Arakan. Oxford University. 
de Chazournes, L. B., \& Condorelle, L. (2000, March 31). Common article 1 of the Geneva Conventions Revisited: Protecting collective interests. ICRC. https://www.icrc.org/eng/resources/documents/article/other/57jqcp.htm

Fleck, D. (Ed.). (2021). The handbook of international humanitarian law. Oxford University.

Fong, J. (2008). Revolution as Development: The Karen Self-Determination Struggle Against Ethnocracy (1949-2004). BrownWalker.

Harroff-Tavel, M. (1993, June 30). Action taken by the International Committee of the Red Cross in situations of internal violence. ICRC. https://www.icrc.org/en/doc/resources/documents/article/other/57jmhy.htm

Henckaerts, J. M. (2005). Customary International Humanitarian Law: Volume 1, Rules (Vol. 1). Cambridge University.

Isti'anah, A. (2018). Rohingya in media: Critical discourse analysis of Myanmar and Bangladesh newspaper headlines. Language in the Online and Offline World, 6, 1823. http://repository.usd.ac.id/id/eprint/25962

Jacob, C. (2014). Practising civilian protection: Human security in Myanmar and Cambodia. Security Dialogue, 45(4), 391-408. https://journals.sagepub.com/doi/abs/10.1177/0967010614535831

Jacob, C. (2016). Civilian protection in the Twenty-first Century. Oxford University.

Jaythoum, M. A. (2020). The legal value of common article third of the Four Geneva Conventions of 1949. PalArch's Journal of Archaeology of Egypt/Egyptology, 17(6), 15538-15548. https://www.archives.palarch.nl/index.php/jae/article/view/6407

Khan, A., \& Hussain Shah Jillani, M. A. (2019). Killer Robots and Their Compliance with the Principles of Law of War. Journal of Law and Society, 1(75). 55. https://heinonline.org/HOL/LandingPage?handle=hein.journals/jlsup50\&div=12\&id $=$ \&page $=$

Kipgen, N. (2014). Addressing the Rohingya problem. Journal of Asian and African Studies, 49(2),

234-247.

https://journals.sagepub.com/doi/abs/10.1177/0021909613505269

Kofi Annan Foundation. (2017, August 24). Advisory commission on Rakhine STATE: Final report. Kofi Annan Foundation. https://www.kofiannanfoundation.org/mediationand-crisis-resolution/rakhine-final-report/

Lane, L. (2016). Mitigating humanitarian crises during non-international armed conflicts: The role of human rights and ceasefire agreements. Journal of International Humanitarian Action, 1(1), 1-19. https://jhumanitarianaction.springeropen.com/articles/10.1186/s41018-016-0002-z

Lut, Z. (2021). Armed Conflict, Internally Displaced Persons, and protection mechanism in Kachin State case study: Laiza, Myanmar-China border, Kachin state, Myanmar.

MacInnis, L. (2007, June 29). International red cross Issues rare Myanmar censure. Reuters. https://www.reuters.com/article/idUSL28287051

McPherson, P. (2018, September 5). Rohingya protesters call for freedom FOR jailed reporters in Myanmar. The Globe and Mail. https://www.theglobeandmail.com/world/articlerohingya-protesters-call-for-freedom-for-jailed-reporters-in-myanmar

Menager, J. (2017). Myanmar's New Generation: A study of elite young people in Yangon, 2010 to 2016. Menager, J. (2017). Myanmar's New Generation: A study of elite young people in Yangon, 2010 to 2016. Autsralian National University. https://openresearch-repository.anu.edu.au/handle/1885/144288 
Meron, T. (1996). The continuing role of custom in the formation of international humanitarian law. American Journal of International Law,90(2), 238-249. https://doi.org/10.2307/2203686

Mohdin, A. (2019). A brief history of the word "Rohingya" at the heart of a humanitarian crisis. Quartz. https://qz.com/1092313/a-brief-history-of-the-word-rohingya-at-the-heartof-a-humanitarian-crisis/

Olumhense, E. (2017, December 26). Rohingya refugees in Chicago face stress, anxiety after Escaping horrors in Myanmar. Chicago Tribune. https://www.chicagotribune.com/news/local/breaking/ct-met-rohingya-refugeeschicago-20171209-story.html

Sassòli, M., Bouvier, A. A., \& Quintin, A. (2011). How does law protect in war? ICRC.

Shesterinina, A., \& Job, B. L. (2016). Particularized protection: UNSC mandates and the protection of civilians in armed conflict. International Peacekeeping, 23(2), 240-273. https://doi.org/10.1080/13533312.2015.1123628

Sivakumaran, S. (2012). The law of non-international armed conflict. Oxford University.

Story, I. (2012, August 15). The Rohingya: A humanitarian crisis. Al Jazeera. https://www.aljazeera.com/program/inside-story/2012/8/15/the-rohingya-ahumanitarian-crisis .

Susetyo, H. (2019). International Humanitarian Law in internal armed conflict: Implementing common article 3 and additional Protocol II to the Geneva Conventions to internal and horizontal conflicts in Indonesia. terAs Law Review, 3(4). 751-781. https://www.trijurnal.lemlit.trisakti.ac.id/teras-Lrev/article/view/5411

Winminton. (2012). A legal study of the notion of Internal Armed Conflict in International Humanitarian Law and Myanmar. Doctoral Dissertation, Seoul National University Graduate School.

Wilmshurst, E., \& Breau, S. (Eds.). (2007). Perspectives on the ICRC study on customary international humanitarian law. Cambridge University. 